\title{
Phenazine Methosulphate Modulating the Expression of Genes Involved in Yeast to Hyphal Form Signal Transduction in Candida albicans
}

\section{Ashwini Khanderao Jadhav1, Priyanka Jangid1, Rajendra Patil2, Wasudev Gade ${ }^{2}$, Kiran Kharat ${ }^{3}$, Sankunny Mohan Karuppayil ${ }^{*}$}

${ }^{1}$ School of Life Sciences, SRTM University, Nanded, India

${ }^{2}$ Department of Biotechnology, Savitribai Phule Pune Univesity, Pune, India

${ }^{3}$ Department of Biotechnology, Deogiri College, Aurangabad, India

Email: *prof.karuppayil@gmail.com

How to cite this paper: Jadhav, A.K., Jangid, P., Patil, R., Gade, W., Kharat, K. and Karuppayil, S.M. (2017) Phenazine Methosulphate Modulating the Expression of Genes Involved in Yeast to Hyphal Form Signal Transduction in Candida albicans. Advances in Microbiology, 7, 707-718.

https://doi.org/10.4236/aim.2017.711056

Received: October 2, 2017

Accepted: November 7, 2017

Published: November 10, 2017

Copyright $\odot 2017$ by authors and Scientific Research Publishing Inc. This work is licensed under the Creative Commons Attribution International License (CC BY 4.0).

http://creativecommons.org/licenses/by/4.0/ Open Access

\begin{abstract}
Candida albicans has ability to switch from yeast to hyphal form which is an important virulence factor. The objective of the research is to study the effect of Phenazine Methosulphate (PMS) on virulence factors and to study expression profile in yeast to hyphal form transition in C. albicans. Phenazine Methosulphate (PMS) acted as an inhibitor of yeast to hyphal form transition, adhesion and biofilm formation in $C$. albicans. RTPCR study demonstrated that PMS Modulate the expression of genes involved in Ras1-cAMP-Efg1 and Cek1-MAPK signal transduction pathways. Cell cycle of $C$. albicans was arrested at $\mathrm{S}$ phase on treatment of PMS. Hyphal suppressor genes like Tup1, Mig1 and Nrg1 were upregulated by PMS. Based on our data on expression of genes during yeast to hyphal form transition in presence and absence of PMS, we hypothesize that inhibition of hyphal formation may be due to the overexpression of negative regulators of hyphal growth. Targeting of hyphal specific genes involved in these pathways may be a promising strategy for anti-candida drug development.
\end{abstract}

\section{Keywords}

Phenazine Methosulphate, Candida albicans Y-H Form Transition, Biofilm, Tup1, Mig1 and Nrg1

\section{Introduction}

Yeast to Hyphal (Y-H) form morphogenesis is one of the major virulence factors in C. albicans and this may facilitate penetration of epithelial tissues and escape from host immune response [1] [2]. Serum induced Ras mediated signaling pathways 
involve Ras1-cAMP-PKA and Cek1-MAPK pathway responsible for $\mathrm{Y}-\mathrm{H}$ form transition [3]. Y-H transition is negatively regulated by the hyphal suppressor genes, Nrg1, Mig1, Tup1 and Rfg1 [4]. Upregulation of hyphal specific genes are reported during yeast to hyphal form transformation [5]. Targeting of hyphal specific genes involved in these pathways may be a promising strategy for anti-Candida drug development [6]. In this study the effect of Phenazine methosulphate (PMS) on the expression of genes involved in Yeast to hyphal transition is explored.

Phenazine methosulphate (PMS), an analog of 5-methylphenazine-1-carboxylic acid (5 MPCA) is reported to exhibit antifungal activity against hyphal growth and biofilm formation of $C$. albicans in Candida albicans [7] [8]. PMS generate reactive oxygen species (ROS) which is responsible for killing or inhibition of growth in C. albicans [7]. PMS and 5MPCA generally bind with cellular amines covalently and accumulate in the cell leads to killing of $C$. albicans [7] [9].

In this study we have identified the potential targets of PMS in C. albicans. The repositioning of PMS as an antifungal agent could be a promising strategy for the treatment of fungal infections.

\section{Materials and Methods}

\subsection{Medium and Culture Conditions}

The standard strain of Candida albicans ATCC 90028 provided by Institute of Microbial Technology, Chandigarh, India. Yeast extract Peptone Dextrose (YPD) agar medium was used to maintain culture and the culture was stored at $4^{\circ} \mathrm{C}$. PMS and all the media components purchased from HiMedia, India. A single isolated colony of $C$. albicans from YPD agar plate was used to inoculate 50 $\mathrm{ml}$ YPD broth in a $250 \mathrm{ml}$ conical flask. The flasks were incubated for $24 \mathrm{~h}$ in an orbital shaking incubator $(100 \mathrm{rpm})$ at $30^{\circ} \mathrm{C}[10]$.

\subsection{Minimum Inhibitory Concentration}

The effect of PMS on the growth of $C$. albicans in planktonic form was studied by using the standard broth microdilution methodology based on the Clinical Laboratory Standards Institute guidelines (Pfaller et al., 1994). Various concentrations of PMS ranging from 0.062 to $2 \mathrm{mg} / \mathrm{ml}$ were prepared in RPMI-1640 medium in 96 well plates (Costar, Corning Inc. USA). Cell suspension $\left(1 \times 10^{3}\right.$ cells $\mathrm{ml}^{-1}$ ) was added to $100 \mu \mathrm{l}$ of RPMI-1640 medium in each well. The plates were incubated at $35^{\circ} \mathrm{C}$ for $48 \mathrm{~h}$ and growth was analyzed by measuring absorbance at $620 \mathrm{~nm}$ using a microplate reader (Multiskan EX, Thermo Electron Corp. USA). The lowest concentration of PMS which caused a 50\% reduction in the absorbance compared to the control was considered as the minimum inhibitory concentration (MIC) for the growth of $C$. albicans [10].

\subsection{Minimum Fungicidal Concentration (MFC)}

To determine the MFC, Candida cells from the wells containing MIC and above the MIC were used. Aliquots of $10 \mu \mathrm{l}$ from these wells were spread on YPD agar. 
These plates were incubated for $48 \mathrm{~h}$ at $30^{\circ} \mathrm{C}$ and observed for the presence of colonies. No appearance of colonies on the agar plates was noted as fungicidal effect. The lowest concentration of the test molecule in the microplate well from which an aliquot showing no growth was considered as the MFC [11].

\subsection{Adhesion Assay}

The effect of Capric and Caprylic acid on the adherence of $C$. albicans to a solid surface (i.e. polystyrene) was studied using a microplate-based assay. Different series of concentrations were prepared in Phosphate buffered saline (PBS) and of $50 \mu \mathrm{l}$ of aliquots were added in to wells of microtiter plates. The final volume of the assay system in each well was kept at $100 \mu$. The plate is incubated at $37^{\circ} \mathrm{C}$ for $90 \mathrm{~min}$ at $100 \mathrm{rpm}$ in an orbital shaking incubator to allow adherence of cells. The adherence of cells were observed in each well by relative metabolic activity (RMA) using the XTT-assay [10].

\subsection{Biofilm Development Assay}

Biofilm formation was done on tissue culture treated 96-well polystyrene plates. $100 \mu \mathrm{l}$ of Cell suspensions of $1 \times 10^{7}$ cells ml $^{-1}$ were added into each well and allowed to adhere on solid surface at $37^{\circ} \mathrm{C}$ for $90 \mathrm{~min}$ at $100 \mathrm{rpm}$. After adhesion wells were washed with PBS two times. RPMI-1640 medium (200 $\mu$ l) along with various concentrations of PMS were incubated for $48 \mathrm{~h}$ at $37^{\circ} \mathrm{C}$. Developed biofilms were observed under an inverted light microscope (Metzer, India). XTT metabolic assay was used Quantitation of Biofilm growth. Photographs were taken with a Labomed microphotography system (Labomed, India) at $200 \mathrm{X}$ magnification [12].

\subsection{Mature Biofilm Assay}

To determine the activity of the PMS against mature C. albicans biofilms, $24 \mathrm{~h}$ old biofilm was used. Wells were washed with PBS to remove nonadhered planktonic cells. Various concentrations of PMS prepared in RPMI 1640 were added to wells. Plates were incubated for $48 \mathrm{~h}$ and then washed with PBS. Wells were observed for the presence or absence of biofilm using an inverted light microscope (Metzer, India). XTT metabolic assay was used to analyze the biofilm growth [12].

\subsection{XTT Metabolic Assay}

Biofilm growth was quantified using XTT metabolic assay. XTT solution was prepared by mixing $1 \mathrm{mg} / \mathrm{ml}$ of XTT salt in PBS and stored at $20^{\circ} \mathrm{C}$. Menadione (Sigma Aldrich, India) solution was prepared in acetone $(4 \mu \mathrm{M})$ and added to the XTT salt solution. The wells containing biofilms were washed with PBS to remove non-adhered cells and incubated with $100 \mu \mathrm{l}$ of XTT-menadione solution in dark, at $37^{\circ} \mathrm{C}$ for $5 \mathrm{~h}$. Color formation by the water soluble formazan product was measured at $450 \mathrm{~nm}$ using a microplate reader (Multiskan EX, 
Thermo Electron Corp. USA) [12].

\subsection{Yeast to Hyphal (Y-H) Form Morphogenesis Assay}

Serum-induced Y-H transition in C. albicans was studied in a microplate-based assay. A series of concentrations of PMS was prepared in deionized distilled water with $20 \%$ serum. $1 \times 10^{6}$ cells $\mathrm{ml}^{-1}$ Cells were inoculated in test and control wells. The final volume of the assay was $200 \mu \mathrm{l}$. After incubation for $2 \mathrm{~h}$ at $37^{\circ} \mathrm{C}$ in an orbital shaker at $200 \mathrm{rpm}$, formation of germ tubes were observed microscopically. Numbers of yeast cells and hyphae were counted by using an inverted microscope (Metzer, India). Photographs were taken with a Labomed microphotography system at $200 \mathrm{X}$ magnification. Inhibition of $50 \%$ hyphae formation was compared with control and considered as MIC for morphogenesis. [10].

\subsection{Scanning Electron Microscopy}

Adhesion of Candida albicans cells on polystyrene discs $\left(1 \times 10^{7}\right.$ cells $\left./ \mathrm{ml}\right)$ were carried out in 12 -well plates at $37^{\circ} \mathrm{C}$ at $50 \mathrm{rpm}$ for $90 \mathrm{~min}$. Samples were fixed in $2.5 \%$ of glutaraldehyde in $0.1 \mathrm{~mol}$ phosphate buffer $(\mathrm{pH} 7.2)$ for $24 \mathrm{~h}$ at $4^{\circ} \mathrm{C}$. Samples were post fixed in $2 \%$ aqueous solution of osmium tetraoxide for $4 \mathrm{~h}$, and then dehydrated in a series of graded alcohols. The samples were mounted over stubs and gold coating was performed using an automated gold coater. Images were obtained by JOEL 6360 (Japan) scanning electron microscope [12].

\subsection{Hemolytic Activity}

Hemolytic activity was determined by using human red blood cells [13]. Suspension of RBC was diluted 1:10 in PBS. Aliquotes of $100 \mu \mathrm{L}$ from this suspension was added in to $100 \mu \mathrm{L}$ of a different concentration of test molecules in the same buffer in Eppendorff tubes. 1\% Triton X 100 was used for total hemolysis. After incubation of $1 \mathrm{~h}$ at $37^{\circ} \mathrm{C}$ it was centrifuged for $10 \mathrm{~min}$ at $2000 \mathrm{rpm}$ at $20^{\circ} \mathrm{C} .150$ $\mu \mathrm{L}$ from supernatant was transferred to a flat-bottomed microtiter plate, and O.D. is taken at $450 \mathrm{~nm}$. All the experiments were done in triplicates.

The hemolysis percentage was calculated by following formula:

$\%$ of hemolysis $=\left[\left(\mathrm{A}_{450}\right.\right.$ of test compound treated Sample $-\mathrm{A}_{450}$ of buffer treated sample $) /\left(\mathrm{A}_{450}\right.$ of $1 \%$ Triton $\mathrm{X} 100$ treated sample $-\mathrm{A}_{450}$ of buffer treated sample) $] \times 100$

\subsection{Cell Cycle Studies}

C. albicans yeast cells from the log phase were harvested, washed and starved for nutrients for $1 \mathrm{~h}$. cells $\left(10^{3} \mathrm{cfu} / \mathrm{ml}\right)$ were inoculated to each flask containing 50 $\mathrm{ml}$ YPD broth and MIC of PMS. Flask without treatment of PMS was considered as Control. All the flasks were incubated at $30^{\circ} \mathrm{C}$ for $3 \mathrm{~h}$. Cells were centrifuged at $1000 \mathrm{rpm}$ for $5 \mathrm{~min}$. washed and fixed in $1 \mathrm{ml}$ of $70 \%$ ethanol by incubating at room temperature on a rotary shaker (REMI, India) for $30 \mathrm{~min}$. Cells were har- 
vested by centrifugation (Genei, Bangalore, India) at $1000 \mathrm{rpm}$ for $5 \mathrm{~min}$, washed twice with $1 \mathrm{ml}$ of $50 \mathrm{mM}$ Tris ( $\mathrm{pH}$ 7.8). Washed cells were resuspended in $500 \mu \mathrm{l}$ of $50 \mathrm{mM}$ Tris containing $10 \mu \mathrm{g}$ RNase A and incubated for $2 \mathrm{~h}$ at $37^{\circ} \mathrm{C}$. After incubation samples were subjected to protease treatment $(5 \mathrm{mg} / \mathrm{ml}$ pepsin in $0.05 \mathrm{M} \mathrm{HCl}$ ) for $1 \mathrm{~h}$ at $25^{\circ} \mathrm{C}$ to reduce cellular clumps. Cells were harvested by centrifugation and resuspended in $500 \mu$ FACS-buffer $(200 \mathrm{mM}$ Tris/HCl pH 7.5; $200 \mathrm{mM} \mathrm{NaCl} ; 78 \mathrm{mM} \mathrm{MgCl}_{2}$ ). $15 \mu \mathrm{l}$ of propidium iodide (1 $\mathrm{mg} / \mathrm{ml}$ ) was added to each tube and incubated for $30 \mathrm{~min}$ and stored at $4^{\circ} \mathrm{C}$. Before analysis, cells were sonicated for $10 \mathrm{~s}$ and analyzed using a FACS Calibur cytometer (Becton-Dickinson, San Jose, Calif.) and analyzed with Cell Quest 3.0 software [14].

\subsection{Gene Expression Assay}

The expression of hyphal genes during serum induced morphogenesis was measured by using Real Time PCR. C. albicans yeast phase cells $\left(1 \times 10^{6}\right.$ cells $/ \mathrm{ml}$ ) were inoculated and incubated for $90 \mathrm{~min}$ in $20 \%$ serum containing PMS $(0.062 \mathrm{mg} / \mathrm{ml})$. Total RNA was isolated by using RNeasy ${ }^{\circledR}$ Mini Kit (QIAGEN, USA) and converted to cDNA by using SuperScript ${ }^{\circledR}$ III for first strand synthesis (Invitrogen, Life technologies, USA). PCR reactions were conducted by using KAPA SYBR ${ }^{\circledR}$ Fast qPCR Kit Master mix (2x) (BIOSYSTEMS, South Africa) in 96 well PCR plates with preliminary denaturation for 3 min at $95^{\circ} \mathrm{C}$. This was followed by 32 amplifications cycles of denaturation at $95^{\circ} \mathrm{C}$ for $30 \mathrm{~s}$, annealing at $60^{\circ} \mathrm{C}$ for $20 \mathrm{~s}$ and primer extension at $72^{\circ} \mathrm{C}$ for $30 \mathrm{~s}$ (CFX 96 Real time System, Bio-Rad, USA). Primers were purchased from Eurofins $\mathrm{Ge}-$ nomics India Pvt. Ltd. (Table 1). Actin was used as an internal control and the transcript levels of selected genes were calculated using the formula $2^{-\Delta \Delta \mathrm{CT}}$ [15].

\subsection{Statistical Analysis}

Values mentioned are the mean with standard deviations, obtained from three different observations. Values in the control and treatment groups were compared using Student's $t$-test. A value of $p<0.05$ was considered statistically significant [10].

\section{Results}

\subsection{The Anti-Candida Efficacy of Phenazine Methosulphate (PMS)}

PMS inhibited planktonic growth of Candida albicans ATCC 90028 in a concentration dependent fashion (Figure 1). More than $90 \%(p<0.05)$ of the growth was inhibited at $0.062 \mathrm{mg} / \mathrm{ml}$. 99\% of planktonic growth was inhibited by PMS after $48 \mathrm{hrs}$ of exposure at $0.25 \mathrm{mg} / \mathrm{ml}$ (Table 1). PMS caused significant inhibition of developing as well as mature biofilm formation (Figure 1, Figure 2). MIC values for developing biofilm and mature biofilm were $0.25 \mathrm{mg} / \mathrm{ml}$ and 0.5 $\mathrm{mg} / \mathrm{ml}$ respectively. $>70 \%$ of $48 \mathrm{~h}$ old mature biofilm growth was eradicated at $0.5 \mathrm{mg} / \mathrm{ml}$ (Figure 1). MIC values were established for Adhesion for PMS (Table 
2). Adhesion of $C$. albicans ATCC 90,028 to polystyrene plate surface was inhibited significantly $(p<0.05)$ by PMS at $>16 \mu \mathrm{g} / \mathrm{ml}$ (Figure 1$)$. MIC50 for inhibition of adhesion was $16 \mu \mathrm{g} / \mathrm{ml}$ (Table 2). After treatment of PMS $(0.031 \mathrm{mg} / \mathrm{ml})$ on C. albicans caused cell cycle arrest in S phase (Figure 3).

Table 1. Gene specific primers used in qRT-PCR.

\begin{tabular}{|c|c|}
\hline Primers & Sequence $\left(5^{\prime} \rightarrow 3^{\prime}\right)$ \\
\hline ACTIN-F & 5’ATGGACGGTGAAGAAGTTGC 3' \\
\hline ACTIN-R & 5’ACCTCTTTTGGATTGGGCTTCA 3' \\
\hline RAS1-F & 5'GGCCATGAGAGAACAATATA 3' \\
\hline RAS1-R & 5'GTCTTTCCATTTCTAAATCAC 3' \\
\hline PDE 2-F & 5’ ACCACCACCACTACTACTAC 3' \\
\hline PDE 2-R & 5’ AAAATGAGTTGTTCCTGTCC 3' \\
\hline BCY 1-F & 5' CCC AAGCTTATGTCTAATCCTCAACAGCA 3' \\
\hline BCY 1-R & 5’ GGG CTGCAGTTAATGACCAGCAGTTGGGT 3' \\
\hline EFG 1-F & 5’ TATGCCCCAGCAAACAACTG 3' \\
\hline EFG 1-R & 5’ TTGTTGTCCTGCTGTCTGTC3' \\
\hline TEC 1-F & 5’ AGGTTCCCTGGTTTAAGTG 3' \\
\hline TEC 1-R & 5’ ACTGGTATGTGTGGGTGAT 3’ \\
\hline ECE 1-F & 5'-СССТСАACTTGCTCСТTCACC-3' \\
\hline ECE 1-R & 5'-GATCACTTGTGGGATGTTGGTAA-3' \\
\hline CEK 1-F & 5’ AGCTATACAACGACCAATTAA 3' \\
\hline CEK 1-R & 5' CATTAGCTGA ATGCATAGCT 3' \\
\hline HST 7-F & 5’ ACTCCAACATCCAATATAACA 3' \\
\hline HST 7-R & 5’ TTGATTGACGTTCAATGAAGA 3' \\
\hline CPH1-F & 5'ATGCAACACTATTTATACCTC 3' \\
\hline CPH2-R & 5'CGGATATTGTTGATGATGATA 3' \\
\hline CDC35-F & 5'TTCATCAGGGGTTATTTCAC 3' \\
\hline CDC35-R & 5'CTCTATCAACCCGCCATTTC 3' \\
\hline HWP1-F & 5’TGGTGCTATTACTATTCCGG \\
\hline HWP1-R & 5'CAATAATAGCAGCACCGAAG \\
\hline MIG1 & 5’CTTCAACTAGCCTATATTCCGATGG 3' \\
\hline MIG1 & 5'-CTTTCT GTAGGTACCAACAACTAC 3' \\
\hline NRG1-F & 5'CACСТCACTTGCAACCCC \\
\hline NRG1-R & 5’GCCCTGGAGATGGTCTGA \\
\hline TUP1 & 5’ GAGGATCCCATGTATCCCCAACGCACCCAG 3' \\
\hline TUP1 & 5'GGCGACGCGTCGTTTTTTGGTCCATTTCCAAATTCTG 3' \\
\hline
\end{tabular}




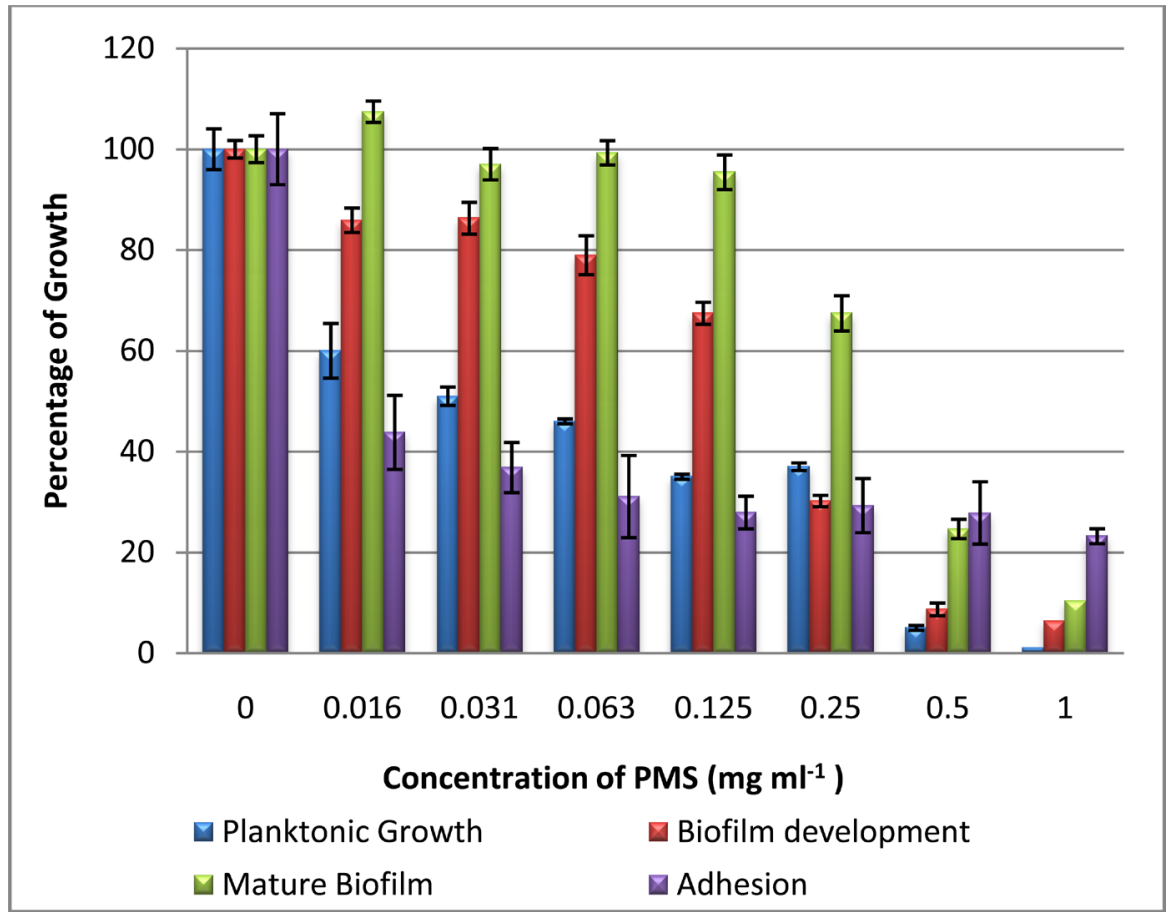

Figure 1. Effect of PMS on C. albicans (ATCC 90,028) Planktonic growth, Developing biofilm, Mature biofilm and Adhesion.

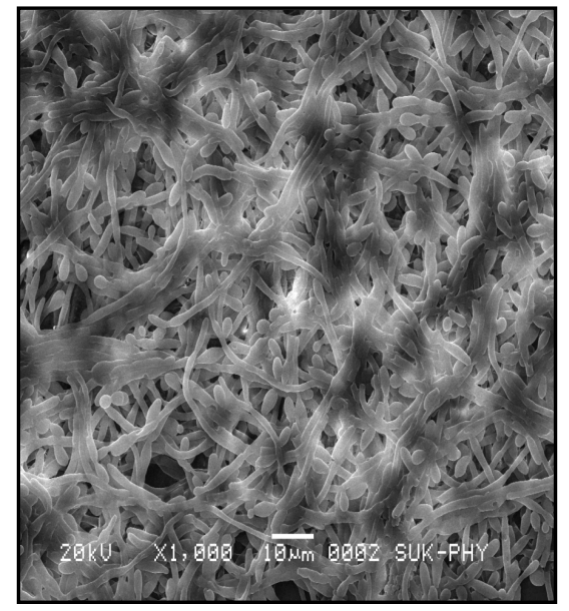

(a)

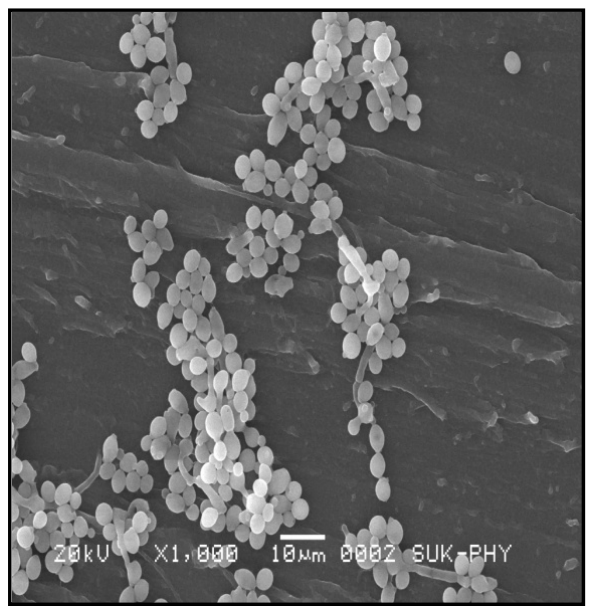

(b)

Figure 2. Scanning electron micrographs (a) Inhibition of Biofilm formation in C. albicans (ATCC 90,028) in presence of PMS $(0.25 \mathrm{mg} / \mathrm{ml})$ (b) Biofilm without treatment of PMS (Control).

Table 2. The efficacies of PMS against $C$. albicans ATCC 90,028, showing the MICs for growth, adhesion, morphogenesis, and biofilm formation and MFCs for planktonic growth.

\begin{tabular}{|c|c|c|c|c|c|c|}
\hline \multirow[b]{2}{*}{ Test Molecule } & \multicolumn{5}{|c|}{$\mathrm{MIC}(\mathrm{mg} / \mathrm{ml})$} & \multirow{2}{*}{$\begin{array}{c}\text { MFC } \\
(\mathrm{mg} / \mathrm{ml})\end{array}$} \\
\hline & $\begin{array}{c}\text { Planktonic } \\
\text { Growth }\end{array}$ & $\begin{array}{l}\text { Developing } \\
\text { Biofilm }\end{array}$ & $\begin{array}{l}\text { Mature } \\
\text { Biofilm }\end{array}$ & Adhesion & $\begin{array}{l}\text { Yeast to Hyphae } \\
\text { Morphogenesis }\end{array}$ & \\
\hline PMS & 0.031 & 0.25 & 0.5 & 0.016 & 0.062 & 0.25 \\
\hline
\end{tabular}




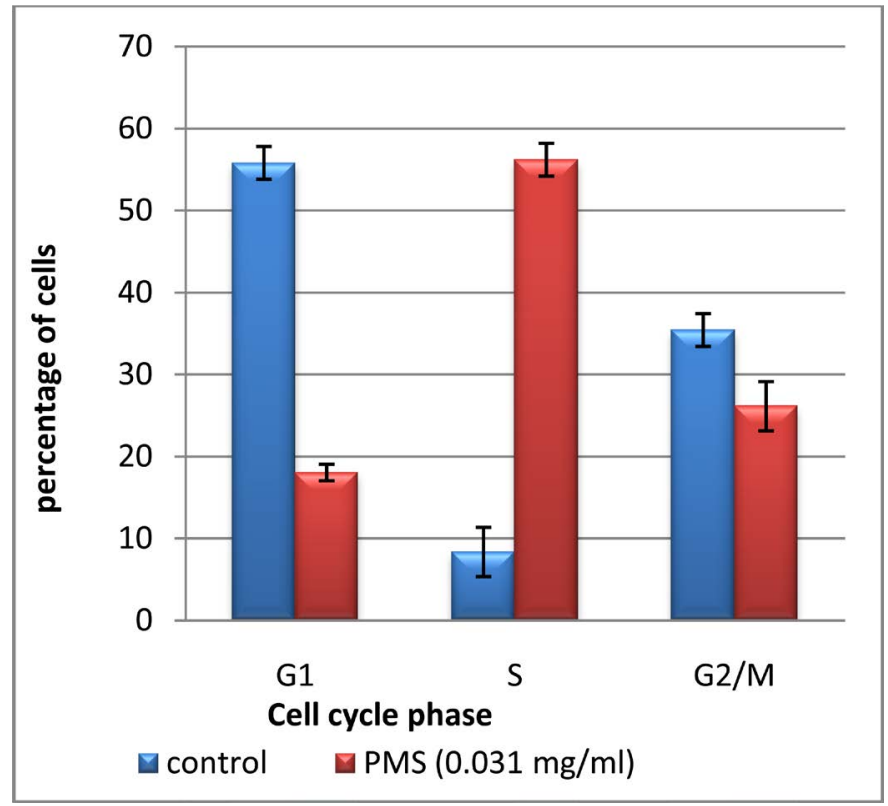

Figure 3. Effect of PMS on Cell cycle of $C$. albicans.

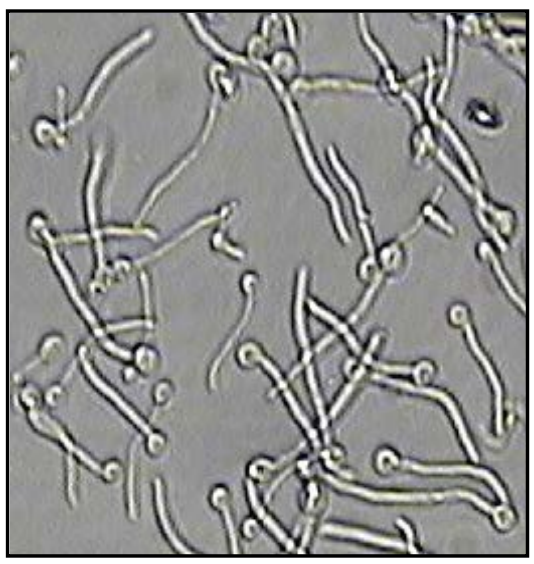

(a)

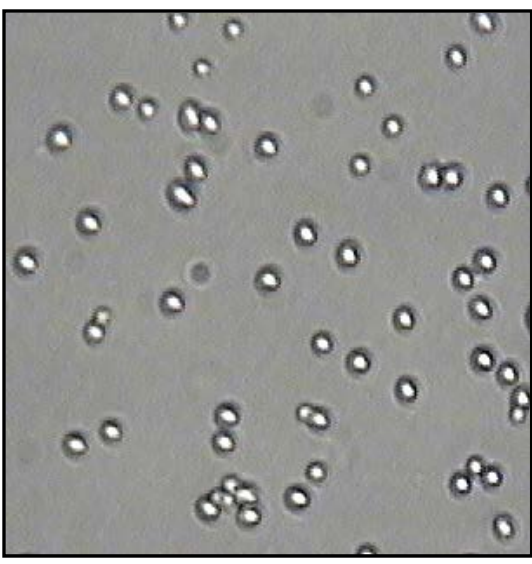

(b)

Figure 4. (a) Serum induced yeast to hyphal form morphogenesis in C. albicans (ATCC 90,028) (Control). (b) Inhibition of serum induced yeast to hyphal form morphogenesis in presence of PMS $(0.062 \mathrm{mg} / \mathrm{ml})$ on $C$. albicans (ATCC 90,028).

\subsection{PMS Inhibited Serum Induced Yeast to Hyphal Form Morphogenesis}

Significant $(p<0.05)$ inhibition of serum induced yeast to hyphal form transition was observed in presence of PMS in a concentration dependent manner. More than fifty percentage inhibition of germ tube induction was found at 0.062 $\mathrm{mg} / \mathrm{ml}$ (Figure 4).

\subsection{PMS Altered the Expression of Genes Involved in Yeast to Hyphal Form transition Pathways}

Since PMS has shown inhibition of serum induced hyphal induction in C. albicans, we analyzed changes in expression levels of the genes involved in Ras1- 
cAMP-Efg1, Cek1-MAPK pathways with quantitative real-time PCR. It was found that the expression of Ras1 which is a master regulator was downregulated up to 1.14 fold $(p<0.05)$ by treatment with PMS. Cdc35 and Pde2, the upstream components of cAMP dependent PKA pathway were upregulated by 1.09 and 1.46 fold respectively. Similarly expression of its downstream components $B c y 1$, $E f g 1$ and $T e c 1$ were upregulated by $2.75,1.12,1.65$ fold. Ecel and Hwpl downstream of Efg1 were significantly downregulated by 1.56 and 11.16 fold respectively (Figure 5). Expression of $H s t 7, C e k 1$ and $C p h 1$ involved in Cek1-MAPK pathways were upregulated by $1.44,1.43$ and 2.57 fold in presence of PMS respectively (Figure 5). Negative regulators of hyphal induction, Nrg1, Mig1 and Tup 1 were upregulated by 1.53, 2.96 fold and 17.95 fold respectively (Figure 5).

\section{Discussion}

PMS, Phenazine derivative showed inhibition of Candida growth and killing of Candida biofilm [7] [8] [16]. PMS inhibited planktonic growth, morphogenesis, biofilm formation and adhesion of Candida albicans ATCC 90,028 (Figure 1). Serum induced yeast to hyphal transition was also inhibited by PMS at 0.062 $\mathrm{mg} / \mathrm{ml}$ (Figure 4). After $3 \mathrm{hr}$ of PMS treatment, it was found that cell cycle of $C$. albicans was arrested at the $S$ phase (Figure 3 ).

Adherence of Candida cells to surface of polystyrene Microtitre plates was analyzed by microscopically and XTT assay. It was found that adhesion was

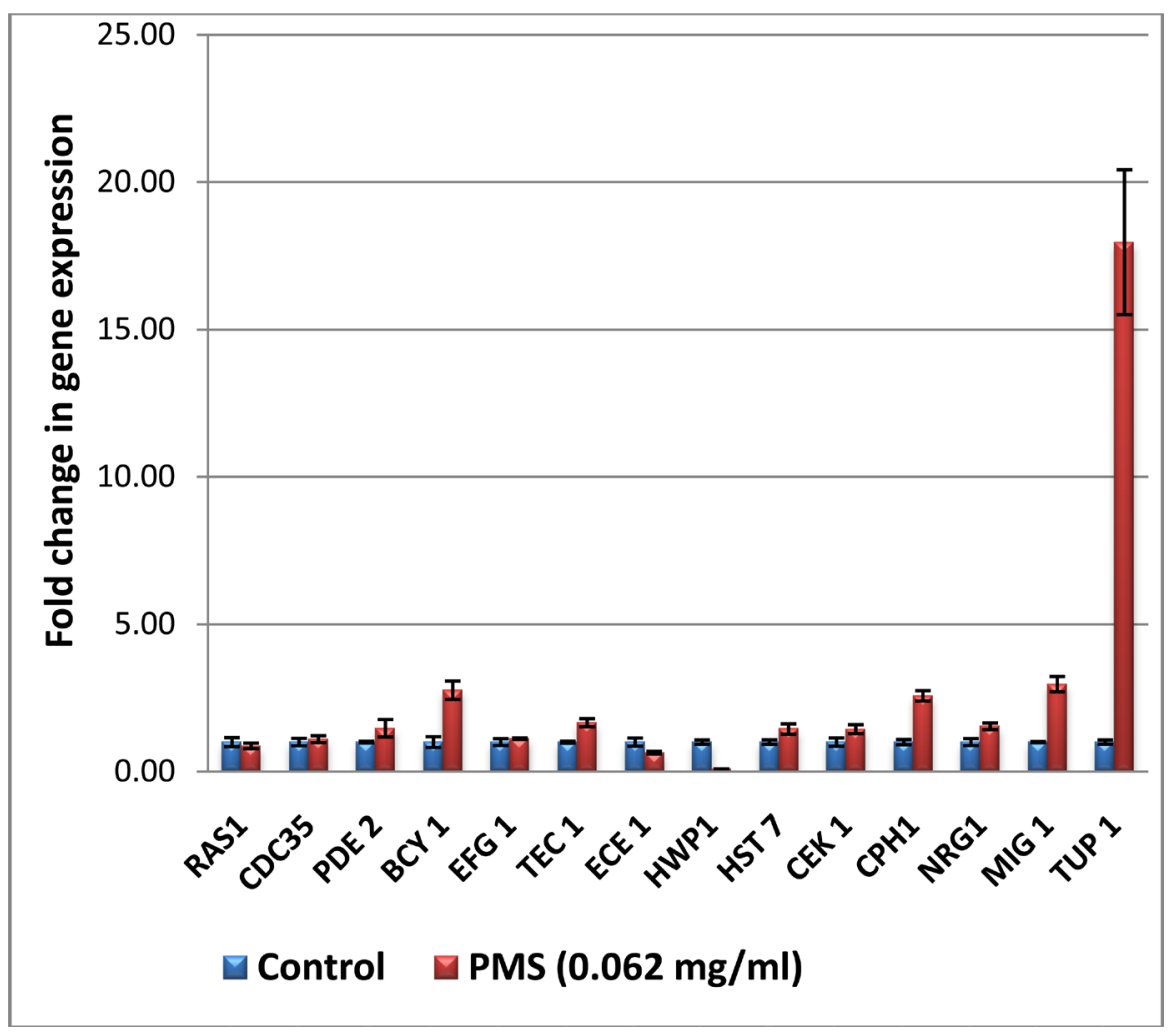

Figure 5. Gene expression profile of Candida albicans during serum induced yeast to hyphal form transition in presence of PMS. 
significantly inhibited by PMS treatment. Adhesion may be inhibited by PMS due to the downregulation of $H w p 1$ expression by 11.16 fold (Figure 5). Hwpl encodes a glycosylphosphatidylinositol-modified cell wall protein that can serve as a target for mammalian transglutaminases to form covalent attachments between C. albicans and host epithelial cells [17].

To know the effect of PMS at the transcription levels during yeast to hypha switching we performed qPCR. Ras 1 gene which is a master regulator of both the pathways [18] was downreguated up to 1.14 fold by treatment with PMS. Expression its downstream components like Efg1 [4] which is a strong inducer of hyphal development was unaffected by the treatment of PMS. The expression of Tec1 was upregulated by 1.65 fold. Ece 1 and Hwp1 are downstream of Efg 1 were significantly downregulated by 1.56 and 11.16 fold respectively (Figure 5). Ece1 is required for cell elongation in $C$. albicans and $H w p 1$ is associated with adhesion and biofilm formation [17] [19]. In addition Cek1-MAPK pathway was affected by change in expression of Hst 7 followed by Cek1 and Cph1. Their expression was slightly upregulated by 1.44, 1.43 and 2.57 fold respectively. Cph1 in $C$. albicans is regulated by a mitogen-activated protein MAP kinase cascade that includes Cst20, Hst7, and Cek1 [20] [21] [22].

Hyphal suppressor gene like $\mathrm{Nrg1}$, Mig1 and $R f g 1$ suppresses hyphal induction [4] [23] [24] and Tup1 repressor which is constitutively expressed forms a complex with MIG1, RFG1 and NRG1 negative regulators and thereby inhibit the activity of hyphal specific gene [4]. Tupl encodes a transcriptional repressor that negatively controls filamentous growth in Candida albicans [4]. Expression of Nrg1, a negative regulator of hyphal induction was upregulated by 1.53 fold by treatment of PMS. Similarly Mig1 and Tup1 over expressed by 2.96 fold and 17.95 fold (Figure 5).

\section{Conclusion}

Our in vitro study revealed that PMS inhibited major virulence factors in C. albicans like morphogenesis and adhesion. qPCR studies showed that PMS affects the signal transduction pathways in yeast to hyphal transition in C. albicans. Most of the genes involved in serum induced Ras1-cAMP-Efg1 and Cek1-MAPK pathway were affected differentially by the treatment with PMS. Upregulation of Hyphal suppressor gene like Tup1 may result in inhibition of yeast to hyphal induction. PMS arrested the cell cycle of $C$. albicans at $S$ phase. PMS did not cause hemolysis of RBCs at the effective concentrations. PMS like molecules could be good molecules to treat candidiasis. In vivo studies need to be done to confirm the anti-Candida efficacy of PMS.

\section{Acknowledgements}

AKJ and SMK are thankful to Prof. Pandit Vidyasagar, Vice Chancellor, SRTM University, Nanded for his kind support. SMK is also thankful to UGC, New Delhi for SAP DRS II Program for infrastructural support. WNG and RP are 
thankful to the Department of Biotechnology Research and Development grant, Savitribai Phule Pune University, Pune, India.

\section{Conflict of Interest}

Authors declare that there is no Conflict of Interest.

\section{References}

[1] Calderone, R.A. and Fonzi, W.A. (2001) Virulence Factors of Candida albicans. Current Trends in Microbiology, 9, 327-335. https://doi.org/10.1016/S0966-842X(01)02094-7

[2] Kumamoto, C.A. and Vinces, M.D. (2005) Contributions of Hyphae and Hypha-Co-Regulated Genes to Candida albicans Virulence. Cellular Microbiology, 7, 1546-1554. https://doi.org/10.1111/j.1462-5822.2005.00616.x

[3] Biswas S., Van Dijck P. and Datta, A. (2007) Environmental Sensing and Signal Transduction Pathways Regulating Morphopathogenic Determinants of Candida albicans. Microbiology and Molecular Biology Reviews, 71, 348-376. https://doi.org/10.1128/MMBR.00009-06

[4] Braun, B.R., Kadosh, D. and Johnson, A.D. (2001) NRG1, a Repressor of Filamentous Growth in $C$. albicans, is Down-Regulated during Filament Induction. EMBO Journal, 20, 4753-4761. https://doi.org/10.1093/emboj/20.17.4753

[5] Carlisle, P.L., Banerjee, M., Lazzell, A., Monteagudo, C., López-Ribot, J.L. and Kadosh, D (2009) Expression Levels of a Filament-Specific Transcriptional Regulator Are Sufficient to Determine Candida albicans Morphology and Virulence. Proceedings of the National Academy of Sciences, 106, 599-604. https://doi.org/10.1073/pnas.0804061106

[6] Jacobsen, I.D., Wilson, D., Wächtler, B., Brunke, S., Naglik, J.R. and Hube, B. (2012) Candida albicans Dimorphism as a Therapeutic Target. Expert Review of Anti-Infective Therapy, 10, 85-93. https://doi.org/10.1586/eri.11.152

[7] Morales, D.K. and Hogan, D.A. (2010) Candida albicans Interactions with Bacteria in the Context of Human Health and Disease. PLOS Pathogens, 6, 1-4. https://doi.org/10.1371/journal.ppat.1000886

[8] Morales, D.K., Jacobs, N.J., Rajamani, S., Krishnamurthy, M., Cubillos-Ruiz, J.R. and Hogan, D.A. (2010) Antifungal Mechanisms by Which a Novel Pseudomonas aeruginosa Phenazine Toxin Kills Candida albicans in Biofilms. Molecular Microbiology, 78, 1379-1392. https://doi.org/10.1111/j.1365-2958.2010.07414.x

[9] Gibson, J., Sood, A. and Hogan, D.A. (2009) Pseudomonas aeruginosa-Candida albicans Interactions: Localization and Fungal Toxicity of a Phenazine Derivative. Applied and Environmental Microbiology, 75, 504-513. https://doi.org/10.1128/AEM.01037-08

[10] Raut, J.S., Shinde, R.B., Chauhan, N.M. and Mohan Karuppayil, S. (2013) Terpenoids of Plant Origin Inhibit Morphogenesis, Adhesion, and Biofilm Formation by Candida albicans. Biofouling, 29, 87-96. https://doi.org/10.1080/08927014.2012.749398

[11] Routh, M.M., Raut, J.S. and Karuppayil, S.M. (2011) Dual Properties of Anticancer Agents: An Exploratory Study on the in Vitro Anti-Candida Properties of Thirty Drugs. Chemother, 57, 372-380. https://doi.org/10.1159/000330454

[12] Shinde, R.B., Raut, J.S. and Karuppayil, S.M. (2012) Biofilm Formation by Candida albicans on Various Prosthetic Materials and Its Fluconazole Sensitivity: A Kinetic Study. Mycoscience, 53, 220-226. https://doi.org/10.1007/S10267-011-0155-Y 
[13] Rajput, S.B. and Karuppayil, S.M. (2013) $\beta$-Asarone, an Active Principle of Acorus calamus Rhizome, Inhibits Morphogenesis, Biofilm Formation and Ergosterol Biosynthesis in Candida albicans. Phytomedicine, 20, 139-142.

[14] Zore, G.B., Thakre, A.D., Jadhav, S. and Karuppayil, S.M. (2011) Terpenoids Inhibit Candida albicans Growth by Affecting Membrane Integrity and Arrest of Cell Cycle. Phytomedicine, 18, 1181-1190.

[15] Chang, W., Li, Y., Zhang, L., Cheng, A. and Lou, H. (2012) Retigeric Acid B Attenuates the Virulence of Candida albicans via Inhibiting Adenylyl Cyclase Activity Targeted by Enhanced Farnesol Production. PLOS ONE, 7, 1-10.

[16] Tupe, S.G., Kulkarni, R.R., Shirazi, F., Sant, D., Joshi, S.P. and Deshpande, M.V. (2015) Possible Mechanism of Antifungal Phenazine-1-Carboxamide from Pseudomonas sp. against Dimorphic Fungi Benjaminiella poitrasii and Human Pathogen Candida albicans. Journal of Applied Microbiology, 118, 39-48. https://doi.org/10.1111/jam.12675

[17] Staab, J.F., Bradway, S.D., Fidel, P.L. and Sundstrom, P. (1999) Adhesive and Mammalian Transglutaminase Substrate Properties of Candida albicans Hwp1. Science, 283, 1535-1538. https://doi.org/10.1126/science.283.5407.1535

[18] Feng, Q., Summers, E., Guo, B. and Fink, G. (1999) Ras Signaling Is Required for Serum-Induced Hyphal Differentiation in Candida albicans. Journal of Bacteriology, 181, 6339-6346.

[19] Nobile, C.J., Andes, D.R., Nett, J.E., Smith, F.J., Yue, F., Phan, Q.T., Edwards, J.E., Filler, S.G. and Mitchell, A.P. (2006) Critical Role of Bcr1-Dependent Adhesins in C. albicans Biofilm Formation in Vitro and in Vivo. PLOS Pathogens, 2, 636-649. https://doi.org/10.1371/journal.ppat.0020063

[20] Csank, C., Schröppel, K., Leberer, E., Harcus, D., Mohamed, O., Meloche, S., Thomas, D.Y. and Whiteway, M. (1998) Roles of the Candida albicans Mitogen-Activated Protein Kinase Homolog, Cek1p, in Hyphal Development and Systemic Candidiasis. Infection and Immunity, 66, 2713-2721.

[21] Köhler, J.R. and Fink, G.R. (1996) Candida albicans Strains Heterozygous and Homozygous for Mutations in Mitogen-Activated Protein Kinase Signaling Components Have Defects in Hyphal Development. Proceedings of the National Academy of Sciences, 93, 13223-13228. https://doi.org/10.1073/pnas.93.23.13223

[22] Leberer, E., Harcus, D., Broadbent, I.D., Clark, K.L., Dignard, D., Ziegelbauer, K., Schmidt, A., Gow, N.A., Brown, A.J. and Thomas, D.Y. (1996) Signal Transduction through Homologs of the Ste20p and Ste7p Protein Kinases Can Trigger Hyphal Formation in the Pathogenic Fungus Candida albicans. Proceedings of the National Academy of Sciences, 93, 13217-13222. https://doi.org/10.1073/pnas.93.23.13217

[23] Kadosh, D. and Johnson, A.D. (2005) Induction of the Candida albicans Filamentous Growth Program by Relief of Transcriptional Repression: A Genome-Wide Analysis. Molecular Biology of the Cell, 16, 2903-2912. https://doi.org/10.1091/mbc.E05-01-0073

[24] Murad, A.M., Leng, P., Straffon, M., Wishart, J., Macaskill, S., MacCallum, D., Schnell, N., Talibi, D., Marechal, D., Tekaia, F. and d'Enfert, C. (2001) NRG1 Represses Yeast-Hypha Morphogenesis and Hypha-Specific Gene Expression in Candida albicans. The EMBO Journal, 20, 4742-4752. https://doi.org/10.1093/emboj/20.17.4742 